Eastern Illinois University

The Keep

Faculty Research \& Creative Activity

Biological Sciences

June 2009

\title{
Influence of Reproductive and Environmental Factors on Population Size .. of Wild Hyacinth [Camassia angusta (Engelm. and A. Gray) Blank. (Liliaceae)], an Illinois Endangered Species
}

Kevin M. Franken

Eastern Illinois University

Janice M. Coons

Eastern Illinois University

Henry R. Owen

Eastern Illinois University, hrowen@eiu.edu

Eric L. Smith

Illinois Department of Natural Resources

John E. Ebinger

Eastern Illinois University

Follow this and additional works at: http://thekeep.eiu.edu/bio_fac

Part of the Biology Commons

\section{Recommended Citation}

Franken, Kevin M.; Coons, Janice M.; Owen, Henry R.; Smith, Eric L.; and Ebinger, John E., "Influence of Reproductive and Environmental Factors on Population Size .. of Wild Hyacinth [Camassia angusta (Engelm. and A. Gray) Blank. (Liliaceae)], an Illinois Endangered Species" (2009). Faculty Research \& Creative Activity. 134.

http://thekeep.eiu.edu/bio_fac/134

This Article is brought to you for free and open access by the Biological Sciences at The Keep. It has been accepted for inclusion in Faculty Research \& Creative Activity by an authorized administrator of The Keep. For more information, please contact tabruns@eiu.edu. 
Influence of reproductive and environmental factors on population size of wild hyacinth [Camassia angusta (Engelm. and A. Gray) Blank. (Liliaceae)], an Illinois endangered species.

Kevin M. Franken, Janice M. Coons, Henry R. Owen, Eric L. Smith, and John E. Ebinger

ABSTRACT Wild hyacinth (Camassia angusta) is a perennial species native to mesic prairies of the midwestern and south-central United States. In Illinois, the only extant population of this state-endangered species is in a small section of degraded black-soil prairie along a railroad track right-of-way south of Elwin, Macon County. The objectives of this study were to determine the population status, seed production, and effects of scarification and stratification on germination of $\mathrm{C}$. angusta. The population was surveyed from 1990 to 2007. A survey of other plant species present was conducted in 1999. The site consisted of approximately $75 \%$ native and 25\% exotic species. The number of flowering stems of Camassia angusta fluctuated significantly (28 to 169 plants) during the course of this study. Prescribed spring burns and a construction equipment disturbance may be partially responsible for these fluctuations. A large percentage of undeveloped fruit, resulting in low seed production $(<3,000)$, as well as low seed germination $(8 \%)$, may be responsible for this population's inability to increase consistently in number of individuals.

\section{INTRODUCTION}

Wild hyacinth or prairie camas, Camassia angusta (Engelm. and A. Gray) Blank. (Liliaceae), is a mesic prairie forb listed as endangered in Illinois (Herkert and Ebinger 2002) and Indiana (Indiana Department of Natural Resources 2007). Distributed throughout much of the s.outh-central United States, this perennial herb also occurs in Arkansas, Iowa, Kansas, Louisiana, Mississippi, Missouri, Oklahoma, and Texas (United States Department of Agriculture, Natural Resources Conservation Service 2007).

Camassia angusta is a long-lived perennial with a bulb diameter of $1-3 \mathrm{~cm}$, linear basal leaves 20-60 cm long by 5-20 mm wide, a single stout scope $27-87 \mathrm{~cm}$ long terminated by a raceme of 3-merous, polypetalous flowers 6-10 mm across, and capsules. with 2-5 seeds per locule (Ranker and Hogan 2002). Camassia angusta is similar to the closely - related C. scilloides (Raf.) Cory qnd sometimes is considered a synonym of that species. Ranker and Schnabel (1986) concluded that they are distinct species. This taxon differs from C. scilloides in having 3-24 persistent bracts scattered along the scope, the perianth is deep lavender to pale purple instead of light blue, and the capsules are longer than they are broad (Mohlenbrock 2002). Also, C. scilloides flowers in April, while C. angusta begins flowering in May (Mohlenbrock 2002, Ranker and Schnabel 1986). Correll and Johnston (1970) concluded that "a phase that blooms later and has small flowers with erect segments is sometimes referred to as C. angustata." 
In Illinois, the only extant $\mathrm{C}$. angusta population occurs between agricultural fields and Illinois Route 51 along a railroad rightof-way in a degraded black-soil prairie south of Elwin, Macon County, in the Grand Prairie Section of the Grand Prairie Natural Division of Illinois (Schwegmann 1973). In 1988 and 1989, only cin estimated 100 and 200 flowering plants were observed, respectively (Taft 1989). Hence, the site was designated a Natural Heritage Landmark by the Illinois Nature Preserves Commission in the early 1990s. The population is found along a two kilometer length of the railroad; however, the plants are not uniformly distributed along its length. Within the population, seven concentrations of individuals were . identified and termed "colonies." The colonies range from approximately $6 \mathrm{~m}$ to 250 $\mathrm{m}$ apart. The population occurs in an area about $24 \mathrm{~m}$ wide. Steyermark (1961) notes an herbarium specimen from Peoria County, but Herkert and Ebinger (2002) indicate that the species likely has been extirpated from that location.

Much of the Elwin site is dominated by nearly pure stands of Bromus inermis, along with a few areas dominated by weedy species, and a few sections of degraded blacksoil prairie. This plant community is degraded by fire suppression, woody species invasion, the prevalence of exotic taxa, and disturbances by construction and railroad activities (Taft 1989). Threats to Camassia angusta in Illinois make it important to understand its reproductive biology to improve management decisions. Without adequate and accurate knowledge about the reproductive biology of this species, its survival in Illinois is at great risk.

Factors, such as its inability to set a high proportion of viable seed, may affect the ability of this species to survive. Previously published accounts noted that flowers of Camassia angusta frequently do not become fertilized (Gould 1942, Steyermark 1961). No published information on the germination of $C$. angusta was found, but in a closely related species, C. scilloides, $67 \%$ of seeds germinated in late March to early April when planted the previous June (Carol Baskin, pers. comm. 2000), and stratification at $1-2^{\circ} \mathrm{C}$ for 3-4 mo was recommended for germination (Horvath et al. 2001).

The objectives of this study were to: 1) examine the number of flowering Camassia angusta plants at the Elwin site from 1990-2007; 2) determine what other plant species were present to assess the quality of the prairie; 3 ) estimate the C. angusta

seed production at the Elwin site; 4) test the effects of scarification and stratification on the germination of C. angusta; and, 5) track changes in the numbers of flowering plants of $\mathrm{C}$. angusta at this site following burns and disturbance.

\section{MATERIALS AND METHODS}

Previous surveys of the Camassia angusta population were conducted in June 1990 and again in 1993, 1994, and 1995 by counting the number of mature plants (i.e., inflorescences) in the railroad prairie south of Elwin, Illinois (Bob Szafoni, pers. comm.). Flowering plants were used as a gauge of population size, since nonflowering plants were never observed. Our study continued these surveys from 
1996 to 2007. Areas within the population where several mature C. angusta plants were found were designated as seven numbered colonies, unevenly distributed along its total length of two kilometers. The closest colonies were 6-8 m apart; the farthest colonies were about $250 \mathrm{~m}$ apart.

Prescribed burning was conducted at the site in 1993, 1994, 1997, 1998, and 2000 as part of a management strategy for the prairie and Camassia angusta. Burns of selected colonies were conducted between March 1 and April 15 by experienced individuals, under specific favorable weather conditions, and in compliance with state and local permits. Techniques included flank and head strip fires. Increases, decreases, or no change in the number of flowering plants in each of seven colonies for each of fourteen years (1994-2007), relative to the previous year, was determined for the purpose of tracking the effects of spring burns $(n=24)$ vs. no burns $(n=72)$.

In the spring of 1994, the Illinois Department of Transportation (IDOT) accidently damaged three of the Camassia angusta colonies (1, 3, and 4) at Elwin Botanical Area Natural Heritage Landmark during construction of Route 51. IDOT had attempted to fence off the sensitive area prior to construction, per agreement with the Illinois Department of Natural Resources (IDNR); however, the wrong area was fenced.

During the summer of 1999, all associated vascular plant species visually observed were recorded, and many were collected. Voucher specimens were numbered and deposited in the Stover-Ebinger Herbarium of Eastern Illinois University. Nomenclature follows Mohlenbrock (2002).

On June 29, 1999, the height of each C. angusta inflorescence (from lowest pedicel to top of inflorescence) was measured, and the numbers of pedicels and/or fruits per plant were counted. At that time, a sample of 60 fruits of C. angusta was collected from 18 plants from colonies 1 and 7 . In the laboratory, seeds were removed from the fruit, and the total number of seeds/fruit was counted. An estimate of total seed production was calculated.

Three seed treatments were used: control, scarification, and stratification. The control and scarified seeds were stored at room temperature from June 29 until December 6, 1999. The stratified seeds were stored at room temperature until October 4, 1999. Each treatment had 5 replications with 10 seeds/ Petri dish $(90 \mathrm{X}$ $15 \mathrm{~mm}$ glass) for a total of 50 seeds/treatment. Control seeds were neither scarified nor stratified. Seeds were scarified by nicking the apex with a razor blade on December 6, 1999. Seeds receiving stratification were soaked in water overnight, placed in moist paper towels, put in a Ziploc ${ }^{\mathrm{TM}}$ plastic bag, and stored in a refrigerator at sac for 63 days. All seeds were soaked in water overnight prior to germination treatments being initiated on December 6, 1999. 
Germination trials were conducted in Petri dishes on 2 layers of Whatman \#1 filter paper, wetted with $5 \mathrm{ml}$ of deionized water, and placed in a germinator at $25^{\circ} \mathrm{C}$ with a $16 \mathrm{hr}$-light $/ 8 \mathrm{hr}$-dark photoperiod and an average light intensity of $4711 \mathrm{~mol} / \mathrm{m} 2$ /sec. All dishes were placed inside a clear plastic tub as an added precaution against the loss of water by evaporation. Seeds were watered when necessary to maintain moisture. Germinated seeds were counted daily for $40 \mathrm{~d}$, with germination defined as emergence of the radicle and/or the embryonic leaves from the seed coat. Twenty seeds that failed to germinate (for each of the three treatments) were tested for viability using 2,3,5-triphenyl tetrazolium chloride (Cottrell 1947). These seeds were cut in half with a razor blade, and a drop of $1 \%$ tetrazolium was placed on the cut end of each seed half. After $12 \mathrm{hr}$, the seeds were checked for viability. A pink color indicated cellular respiration and, thus, seed viability.

Data were analyzed by calculating means, minima, maxima, and standard deviations. Mean separations for germination data were based on Duncan's Multiple Range Test at $5 \%$ level after analysis of variance (ANOV A) using CoStat programs (CoStat 1995).

\section{RESULTS}

From 1990 to 2007 (no data were collected in 1991 and 1992), the overall number of inflorescences of Camassia angusta observed in the entire population fluctuated significantly (Table 1). In terms of the total number of inflorescences per year, the highest (169 plants) was in 2006, and the lowest (28 plants) was in 1994. In 1993, the population increased to its second highest peak of 168 individuals. From 1996 to 2001 , the number of inflorescences changed little, with 49 inflorescences observed in 2001. By 2002, the population doubled, then dropped to 85 in 2003, 86 in 2004, and 80 in 2005. In 2006, the population had more than doubled from the previous year to 169 and then dropped to 47 in 2007.

In a 1999 survey of the study site, 67 native and 29 exotic species were encountered (Appendix 1). Of these, black-soil tall-grass species accounted for 55 of the taxa and were mostly restricted to small degraded patches of prairie that rarely exceeded a few hundred $\mathrm{m} 2$ in size. The most common vegetation type encountered were large patches of near monocultures of the exotic Bromus inermis and Phalaris arundinacea and the native Persicaria amphibium. A few woody species were present (nine encountered), four being native species associated with black-soil prairies.

Based on field observations in 1999, approximately 25\% of Camassia angusta pedicels produced fruit. No apparent pattern was observed for the number or position of pedicels with and without fruit on a given inflorescence. Fruits had an average of seven seeds each. Inflorescences averaged 50 pedicels. An estimate of the total seed production of the population was less than 3,000 (Table 2). Correlations between the number of pedicels and number of fr-uits $(r=0.478, n=18)$ and 
between inflorescence height and number of fruits $(r=0.582, \mathrm{n}=18)$ were both found to be significant at the 0.05 level.

Table 1. Number of inflorescences in each colony of wild hyacinth (Camassia angusta) in a population near Elwin, Illinois (Macon County) during June 1990 to 2007. Spring burn years and burned colonies are indicated in bold type. The disturbance year (1994) and the colonies disturbed are italicized

\begin{tabular}{lcccccccrrr}
\hline Year & Colony 1 & Colony 2 & Colony 3 & Colony 4 & Colony 5 & Colony 6 & Colony 7 & Total & Change \\
\hline 1990 & 57 & 2 & 2 & 4 & 6 & 2 & 8 & 81 & \\
1993 & 136 & 10 & 0 & 16 & 6 & ns & ns & 168 & 87 \\
1994 & 7 & 15 & 0 & 0 & 6 & 0 & 0 & 28 & -140 \\
1995 & 45 & 69 & 0 & 1 & 5 & 23 & 7 & 150 & 122 \\
1996 & 18 & 12 & 0 & 0 & 6 & 12 & 4 & 52 & -98 \\
1997 & 9 & 11 & 0 & 3 & 0 & 8 & 2 & 33 & -19 \\
1998 & 3 & 0 & 0 & 0 & 14 & 36 & 15 & 68 & 35 \\
1999 & 9 & 0 & 0 & 1 & 4 & 4 & 15 & 33 & -35 \\
2000 & 11 & 6 & 3 & 1 & 0 & 14 & 7 & 42 & 9 \\
2001 & 14 & 11 & 2 & 0 & 2 & 17 & 3 & 49 & 7 \\
2002 & 36 & 16 & 0 & 2 & 7 & 28 & 12 & 101 & 52 \\
2003 & 24 & 30 & 0 & 0 & 9 & 16 & 6 & 85 & -16 \\
2004 & 33 & 28 & 0 & 1 & 1 & 17 & 6 & 86 & 1 \\
2005 & 31 & 23 & 0 & 0 & 5 & 20 & 1 & 80 & -6 \\
2006 & 65 & 50 & 0 & 2 & 12 & 31 & 9 & 169 & 89 \\
2007 & 0 & 12 & 5 & 0 & 12 & 18 & 0 & 47 & -122 \\
Mean & 31.1 & 18.4 & 0.8 & 1.9 & 5.9 & 16.4 & 6.3 & 79.5 & 46.6 \\
SD & 33.9 & 18.6 & 1.5 & 3.9 & 4.2 & 10.4 & 4.9 & 46.6 \\
\hline
\end{tabular}

ns $=$ not surveyed.

In the seed germination experiment, none of the control or scarified seeds germinated after $40 \mathrm{~d}$ of observation. Of the stratified seeds, none germinated after $24 \mathrm{hr}$ (posttreatment), 6\% germinated after $48 \mathrm{hr}$, while after $72 \mathrm{hr}$, another $2 \%$ germinated. No additional germination occurred in stratified seeds during $40 \mathrm{~d}$. Germination of stratified seeds (8\%) was significantly higher than for control $(0 \%)$ or scarified ( $0 \%$ ) seeds. Tetrazolium tests showed that $100 \%$ of the tested, ungerminated seeds were viable. After $12 \mathrm{hr}$, all of the cut ends of the seed halves were pink, indicating cellular respiration and, thus, seed viability.

In the five seasons after a prescribed spring bum (conducted in 1993, 1994, 1997, 1998, and 2000), 42\% of total colonies showed an increase in inflorescences while $37 \%$ showed a decrease, and $21 \%$ remained the same (Figure 1). After non-bum seasons, $43 \%$ of total colonies showed an increase in inflorescences, $42 \%$ showed a decrease, and $15 \%$ remained the same.

The significant decrease in the number of flowering plants from 1993 to 1994 may be due to a disturbance by construction equipment, fire, or both (Table 1). In the spring of 1994, construction equipment was driven over colonies 1,3 , and 4, destroying many plants and damaging others, as evidenced by the reduction of flowering plants from 152 to 7 . The disturbance likely contributed to the total decrease in the number of mature plants observed later that same year. In colonies that were disturbed, $67 \%$ suffered a decrease in the number of inflorescences observed later that year while 33\% had no change. By contrast, in colonies that were not disturbed, $60 \%$ had no change, $20 \%$ increased and $20 \%$ had 
a decrease in the number of inflorescences observed later that year. Two of the damaged colonies ( 1 and 4 ) have never returned to their pre-disturbance levels of flowering, now 14 yr post-damage.

Table 2. Inflorescence, fruit, and seed characteristics of wild hyacinth (Camassia angusta) plants in the population south of Elwin, Illinois (Macon County) in June 1999. $n=33$

\begin{tabular}{|c|c|c|c|}
\hline & Mean \pm Standard Deviation & Minimum & Maximum \\
\hline Total \# of pedicels & $50.0 \pm 20.0$ & 23 & 97 \\
\hline \# pedicels with fruit & $12.6 \pm 8.8$ & 1 & 36 \\
\hline \# pedicels without fruit & $37.4 \pm 17.3$ & 14 & 76 \\
\hline$\%$ pedicels with fruit & $25.2 \pm 14.8$ & 2.7 & 55.6 \\
\hline Inflorescence height $(\mathrm{cm})^{z}$ & $16.9 \pm 6.2$ & 6.5 & 27.2 \\
\hline \# inflorescences/population & 33 & - & - \\
\hline \# seeds/fruit & $7.0 \pm 4.5$ & 0 & 18 \\
\hline \# seeds/population (estimate) & 2911 & - & - \\
\hline
\end{tabular}

${ }^{2}$ height from lowest pedicel to top of inflorescence.

\section{DISCUSSION}

Overall, the Camassia angusta population fluctuated significantly in the number of flowering plants from 1990 to 2007. These fluctuations are consistent with Taft (1989) and likely are the result of several biotic and abiotic factors.

Competing vegetation may affect the wild hyacinth population at Elwin in two ways. First, wild hyacinth may be suffering from competition with Bromus inermis (smooth brome), as also reported by Taft (1989), which forms dense stands along much of the railroad right-of-way and has its peak growth at the same time as $\mathrm{C}$. angusta. In addition, Taft reported that the site was invaded by Festuca pratensis (meadow fescue) and Poa pratensis (Kentucky bluegrass), also noted in our survey. Second, its presence along a railroad and agricultural cropland may subject the species to periodic herbicide applications to control unwanted weeds. Drift from herbicide spraying may have affected this population of Camassia angusta negatively in the past (Taft 1989); however, no herbicide damage was readily apparent during this study. IDOT has signs along the roadway . that say "Prairie- Do Not Mow or Spray," but there is no such protection along the privately owned row crop fields. Twenty-eight exotic species were found growing in the area. Most of the competing plants overlie the $\mathrm{C}$. angusta when it is developing fruit, and hence are decreasing light availability as well as soil components.

Prescribed spring burning at the site was sporadic because easterly winds are required to blow smoke safely away from traffic on Illinois Route 51, which borders the population. While fire positively affects flowering and reproduction of many mature prairie grasses and forbs, prescribed spring burns did not stimulate an increase in the number of colonies that increased the following year (43\% to $42 \%$ ) and only slightly decreased the number of colonies that exhibited a decrease in the number of inflorescences ( $42 \%$ to $37 \%$ ). Early spring burns could stimulate wild hyacinth; however, burns may have variable effects on exotic, cool season grasses 

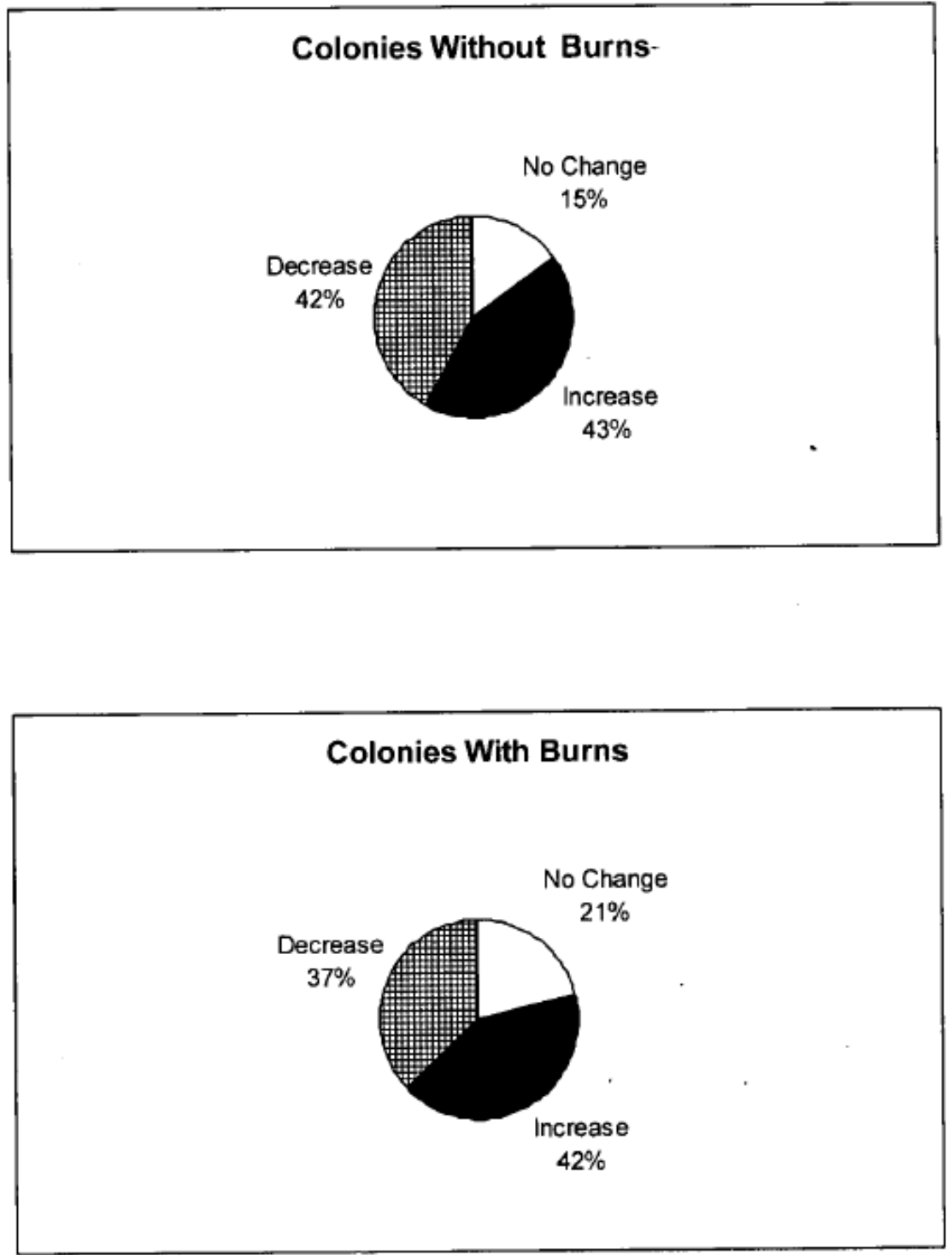

Figure 1. Effects of prescribed burns on the change in number of Camassia angusta inflorescences the following June (compared to the previous June).

which compete with the wild hyacinth, depending on factors such as rainfall and timing (Willson and Stubbendieck 1997). Since the prescribed spring burns, which were intended to increase the wild hyacinth population, did not greatly increase the number of colonies that increased in their number of inflorescences, it is recommended that the efficacy of fall prescribed burns be examined in future studies. Incorporating fall burns into the management regime to increase the success of $\mathrm{C}$. angusta has not materialized in the past several years because a lack of easterly winds has made it unsafe to burn in the fall.

The dramatic reduction of Camassia angusta plants in colonies 1, 3, and 4 in 1994 is likely due to construction equipment damage. Prior to the C. angusta survey in 1994, lOOT ran heavy trenching equipment over an area which included these colonies, 
causing very prominent crushing and trampling of vegetation. Since 1994, IDOT and IDNR have been involved with mitigation plans.

Germination trials determined that scarification does not overcome seed dormancy, but stratification does increase germination to a limited extent. Both control and scarified seeds yielded no germination. Seeds that were stratified yielded only 8\% germination. This germination percentage, obtained in 1999, is significantly lower than those observed by other individuals growing plants from seeds of Camassia angusta harvested at the Elwin site (Ken Schaal and Mike Mason, pers. comm. 2000). A possible reason why the germination percentages in this study were so low might be inadequate stratification techniques, as seeds were viable based on tetrazolium tests. Hence, for some reason their dormancy was not broken. The seeds were stratified at a constant temperature in a refrigerator and on a moistened paper towel. Obviously, these artificial conditions are not identical to those that seeds are normally exposed in the prairie environment. For C. scilloides, stratification at $1-2^{\circ} \mathrm{C}$ for 3-4 mo broke dormancy (Horvath et al. 2001), whereas in the present study with C. angusta, stratification was at soc for 2 mo. Future studies may find higher germination percentages by using lower temperatures, longer stratification treatments, fluctuating temperatures, longer seed-soaking to leach possible inhibitors, and/or by using different media such as sphagnum moss, vermiculite, perlite and/ or sand during stratification. Since all seeds were viable, this limited germination result needs further study to understand the requirements to break dormancy for C. angusta.

The reproductive biology of a plant species is dependent upon many factors including pollination, seed production, and germination. The estimate of less than 3,000 seeds produced by the entire population in 1999 , together with low fruit set (only $25 \%$ of pedicels had fruit) and low seed germination (only 8\%), puts this species in jeopardy of disappearing from Illinois. In addition, our data averaged 50 pedicels per inflorescence, roughly half the average number of flowers per inflorescence observed previously for this species (Ranker and Schnabel 1986). A low level of genetic diversity (possibly from selfpollination, inbreeding depression within colonies) and/or a lack of pollination could be limiting seed production in this population of Camassia angusta. Several other species often grow over the $\mathrm{C}$. angusta, which might make it more difficult for pollinators to find the flowers. Other factors after pollination also could influence the reproduction of $\mathrm{C}$. angusta, such as limited seed development or competition from other plant species. Only $25 \%$ of the pedicels on the wild hyacinths had fruit. This problem also was observed a half century ago (Gould 1942). With this low percentage of fruit set and the low number of plants in the population, limited seed production is hampering long-term population viability and population expansion. The pollination and fertilization strategy of C. angusta is unknown. Knowing when and how wild hyacinth flowers are pollinated would help researchers understand the reproductive biology of this endangered plant species, and perhaps save it from becoming extirpated in Illinois. In order for this population to remain viable and expand, further research must be 
conducted to learn more about this plant's reproductive biology, and conservation management strategies must be developed and implemented at the site. Alternative management strategies may be necessary to maintain this species.

\section{ACKNOWLEDGMENTS}

The authors thank the Council on Faculty Research at Eastern Illinois University (EIU) and the Lewis Hanford Tiffany grant program in the Department of Biological Sciences at EIU for providing funds to support this study. Also, we thank the Illinois Department of Natural Resources for support through its Wildlife Preservation Fund. We acknowledge Michael Mason of the Illinois Department of Natural Resources (IDNR) and Ken Schaal of the Bluestem Prairie Nursery for their advice regarding stratification of $\mathrm{C}$. angusta. Thanks also to Susan Dees of the Illinois Department of Transportation for assistance in managing and monitoring the site, Bob Szafoni (IDNR) for conducting population surveys in 1993, 1994, and 1995, and Carrie DuFrain (EIU student) for assistance with field collections in 1999. We thank Carol Baskin for the germination trial results of C. scilloides.

\section{LITERATURE CITED}

Correll, D.S. and M.C. Johnston. 1970. Manual of the vascular plants of Texas. Texas Research Foundation, Renner, Texas.

CoStat 1995. CoHort Software. Manual revision 5.00. Monterey, California.

Cottrell, H.J. 1947. Tetrazolium salt as a seed germination indicator. Nature 159:748.

Gould, F.W. 1942. A systematic treatment of the genus Camassia Lind!. Amer. Midi. Naturalist 28:712-742.

Herkert, J.R. and J.E. Ebinger (eds.). 2002.

Endangered and threatened species of Illinois:

status and distribution. Volume 1. Plants. Illinois Endangered Species Protection Board, Springfield, Illinois.

Horvath, D.J., G. Blessman, and R.M. Flood. 2001. Propagation protocol for production of container Camassia scil/oides (Raf.) Cory plants $(1+0$ container plugs); Illinois Department of Natural Resources - Mason State Nursery, Topeka, Illinois .. In: Native plant network. URL: http:/ /www.nativeplantnetwork. org (accessed 19 February 2008). University of Idaho, College of Natural Resources, Forest Research Nursery, Moscow, Idaho.

Indiana Department of Natural Resources. 2007. Endangered, threatened, rare, and extirpated plants of Indiana. http:/ /www.in. gov

/dnr/naturepr/endanger/etrplants. pdf, 29 December 2007. Indiana Department of Natural Resources, Indianapolis, Indiana 46204. 
Mohlenbrock, R.L. 2002. Vascular flora of Illinois. Southern Illinois University Press, Carbondale, Illinois.

Ranker, T.A. and T. Hogan. 2002. Camassia. Volume 26. p. 303-307. In: Flora of North America Editorial Committee (eds.). Flora of North America North of Mexico, New York and Oxford.

Ranker, T.A. and A.F. Schnabel. 1986. Allozymic and morphological evidence for a progenitor-derivative species pair in Camassia (Liliaceae). Syst. Bot. 11:433-445.

Schwegmann, J.E. 1973. Comprehensive plan for the Illinois nature preserves system. Part 2. The Natural Divisions of Illinois, Illinois Nature Preserves Commission, Rockford, Illinois.

Steyermark, J .A. 1961. A neglected Camassia. Brittonia 13:206-211.

Taft, J.B. 1989. The noteworthy vegetation of the FAP412 (U.S. 51) alignment for Decatur to Pana, Illinois with emphasis on threatened and endangered plant species and natural areas. Illinois Natural History Survey, Champaign, Illinois. Report to the Illinois Department of Transportation, Springfield, Illinois.

United States Department of Agriculture, Natural Resources Conservation Service. 2007. The PLANTS Database (http://plants. usda.gov, 29 December 2007). National Plant Data Center, Baton Rouge, Louisiana 70874-4490.

Willson, G.D. and J. Stubbendieck. 1997. Fire effects on four growth stages of smooth brome (Bromus inermis). Nat. Areas J. 17:306-312.

\section{APPENDIX I}

The vascular plant species collected at the Camassia site just south of Elwin, Macon County, Illinois (NE1/4 S9 T15N R2E) are listed below by major groups. Collecting numbers are those of John E. Ebinger except for the specimen of Camassia angusta. Specimens are deposited in the Stover-Ebinger Herbarium, Eastern Illinois University, Charleston, Illinois (EIU). Moist black-soil prairie species are indicated by a plus $(+)$. Non-native species are indicated by an asterisk $(*)$. Nomenclature follows Mohlenbrock (2002).

\section{MONOCOTS COMMELINACEAE}

Tradescantia ohiensis Raf.; 27909

\section{CYPERACEAE}


+Carex cristatella Britt.; 27888

+Carex granularis Muhl.; 27895

+Carex gravida Bailey; 27889

+Carex pel/ita Willd.; 27887

+Scirpus atrovirens Willd.; 27923

\section{LILIACEAE}

+Allium canadense L.; 27907

- Allium vineale L.; 27894

*Asparagus officina/is L.; 27908

+Camassia angusta (Engelm. \& A. Gray) Blank.; P.Shildneck

7480

*Hemerocallis fulva (L.) L.; 27924

\section{POACEAE}

+Andropogon gerardii Vitman; 27925

*Bromus inermis Leyss.; 27927

*Bromus tectorum L.; 27938

+Calamagrostis canadensis (Michx.) P. Beauv.; 27910

+Dichanthelium oligosanthes (Schult.) Gould; 27891

+Eiymus canadensis L.; 27926

+Eiymus virgihicus L.; 27899

*Eiytrigia repens (L.) Desv.; 27902

*Festuca pratensis Huds.; 27939

Glyceria striata (Lam.) Hitch.; 2795'1

Hordeum jubatum L.; 27953

*Lolium perenne L.; 27911

+Muh/enbergia frondosa (Poir.) Fern.; 27957

+Panicum virgatum L.; 27973

*Phalaris arundinacea L.; 27958

*Poa compressa L.; 27912

*Poa pratensis L.; 27913

+Schizachyrium scoparium (Michx.) Nash; 27952

+Sorghastrum nutans (L.) Nash.; 27974

Tridens flavus (L.) Hitch.; 27916

\section{TYPHACEAE}

Typha /atifolia L.; observed

DICOTS

ACANTHACEAE

+Ruellia humilis Nutt.; 27940 
ANACARDIACEAE

+Rhus glabra L.; 27959

Toxicodendron radicans (L.) Kuntze; 27960

APIACEAE

*Conium maculatum L.; 27901

*Daucus carota L.; 27941

*Pastinaca sativa L.; 27942

*Tori/is japonica (Houtt.) DC.; 27897

APOCYNACEAE

+Apocynum cannabinum L.; 27961

+Apocynum sibiricum jacq.; 27893

APIACEAE

*Conium maculatum L.; 27901

*Daucus carota L.; 27941

*Pastinaca sativa L.; 27942

*Tori/is japonica (Houtt.) DC.; 27897

APOCYNACEAE

+Apocynum cannabinum L.; 27961

+Apocynum sibiricum jacq.; 27893

ASCLEPIADACEAE

+Asclepias syriaca L.; observed

ASTERACEAE

+Ambrosia artemisiifolia L.; 27962

Ambrosia trifida L.; 27975

+Brickellia eupatorioides (L.) Shinners; 27972

+Cirsium discolor (Muhl.) Spreng.; 27928

+Conyza canadensis (L.) Cronq.; 27971

+Coreopsis tripteris L.; 27976

+Erigeron annuus (L.) Pers.; 27898

+Eupatorium altissimum L.; 28163

+Euthamia graminifolia (L.) Nutt.; 27963

+Helianthus grosseserratus Martens.; 27970

+Lactuca serrio/a L.; 28162

+0/igoneuron rigidum (L.) Small; 27950

+Ratibida pinnata (Vent.) Barnh.; 27914

+Rudbeckia hirta L.; 27915 
+Silphium integrifolium Michx.; 27929

+Silphium /aciniatum L.; 27969

+Solidago canadensis L.; 27917

+Solidago nemora/is Ait.; 27968

*Tragopogon dubius Scop.; 27935

+Vernonia missurica Raf.; 27949

CAPRIFOLIACEAE

*Lonicera maackii (Rupr.) Maxim.; 27918

+Sambucus canadensis L.; 27967

CARYOPHYLLACEAE

*Saponaria officina/is L.; 28165

+Silene antirrhina L.; 28166

CONVOLVULACEAE

*Convolvulus arvensis L.; 28167

ELAEAGNACEAE

*Elaeagnus umbel/ala Thunb.; 27966

121

EUPHORBIACEAE

+Euphorbia corollata L.; 27948

FABACEAE

*Melilotus a/bus Medic.; 27936

*Melilotus officina/is (L.) Pallas.; 27930

*Trifolium pratense L.; 27937

HYPERICACEAE

+Hypericum sphaerocarpum Michx.; 27904

LAMIACEAE

+Monarda flstulosa L.; 27947

*Nepeta cataria L.; 27922

*Stachys palustris L.; 27890 


\section{LYTHRACEAE}

+Lythrum alatum Pursh; 27896

MORACEAE

*Maclura pomifera (Raf.) Schneider; 27946

*Morus alba L.; 27921

NYCTAGINACEAE

*Mirabilis nyctaginea (Michx.) MacM.; 27905

ONAGRACEAE

+Oenothera biennis L.; 27932

POLYGONACEAE

+Persicaria coccinea (Muhl.) Greene; 27945

Rumex altissimus Wood.; 27931

PRIMULACEAE

Lysimachia ciliata L.; 27900

+Lysimachia lanceolata Walt.; 27965

ROSACEAE

+Fragaria virginiana Duchesne; 27956

+Geum /aciniatum Murr.; 27933

+Rosa carolina L.; 27964

+Rubus allegheniensis Porter; 27944

+Rubus flagellaris Willd.; 27955

SALICACEAE

Salix interior Rowlee; 27920

SCROPHULARIACEAE

*Verbascum thapsus L.; 27943

+Veronicastrum virginicum (L.) Farw.; 27954

SOLANACEAE 
Physalis heterophylla Nees; 27903

Solanum carolinen e L.; 27934

\section{VITACEAE}

Vitis vulpina L.; 27919 